\title{
Temperature effects on the feeding and electron transport system (ETS) activity of Gammarus fossarum
}

\author{
Lara Schmidlin · Stefanie von Fumetti • \\ Peter Nagel
}

Received: 14 October 2014/Accepted: 24 January 2015/Published online: 31 January 2015

(C) Springer Science+Business Media Dordrecht 2015

\begin{abstract}
The effects of an increase in water temperature as a direct consequence of global change on organisms living in springs and spring brooks have rarely been studied in laboratory experiments. In this study, experiments were conducted to test the response of Gammarus fossarum Koch, 1836, as an abundant representative of the European spring fauna, to changing water temperatures. The aim was to find out experimentally how $G$. fossarum reacts to varying and increasing water temperatures. The experiments were conducted in flow channels with spring water. In each flow channel, G. fossarum were placed in boxes with a flow-through system for 4 weeks. Two analytical methods were applied: the feeding activity of the amphipods was quantified in order to determine the reaction of G. fossarum on the level of the organism and the respiratory electron transport system (ETS) assay was conducted in order to determine changes in the test organisms on the cellular level. The results show that the feeding activity of $G$. fossarum increased with increasing water temperature, up to an optimum, indicating an increase in their metabolic activity. The
\end{abstract}

Handling Editor: Piet Spaak.

L. Schmidlin $(\varangle) \cdot$ S. von Fumetti · P. Nagel Biogeography Research Group, Department of Environmental Sciences, University of Basel, St. Johanns-Vorstadt 10, 4056 Basel, Switzerland e-mail: lara.schmidlin@unibas.ch
ETS activity does not show significant differences at the different temperatures tested. A possible explanation for this is the ability of the organisms to adapt quickly to the changed environmental circumstances.

Keywords Thermal stress - Amphipod ·

Metabolism $\cdot$ Respiratory chain $\cdot$ Global change

\section{Introduction}

The earth's environment is under constant change, and the fauna of all ecosystems is hence subjected to these changes. Global change is causing heat waves and heavy precipitation events in temperate regions (IPCC 2007) more frequently, and such changes in temperature and precipitation are already noticeable (DellaMarta et al. 2007; Hegerl et al. 2011). It has been shown that freshwaters and their biodiversity are especially vulnerable towards climate change (e.g. Heino et al. 2009; Woodward et al. 2010). Already in the early 1990 s, it was expected that a temperature increase would have a great impact on the structure and functioning of freshwater ecosystems (Carpenter et al. 1992). The water temperature of Swiss rivers has already increased significantly (Vittoz et al. 2013). Springs are relatively temperature-stable ecotones with limited seasonal fluctuations (van der Kamp 1995; Cantonati et al. 2006), and this thermal stability seems to be one of the main characteristics of springs 
fed by deep groundwater (Fischer et al. 1998). However, there is also evidence for certain variability in the temperature regime of springs (Fischer et al. 1998; von Fumetti et al. 2007), and since global change is causing more extreme weather events, the variability of the water temperature will become larger.

Gammarus fossarum Koch, 1836 (Crustacea; Amphipoda), is a relatively robust representative of the macrozoobenthos of springs. Since it inhabits springs and spring brooks abundantly, mainly in the central and eastern mountainous areas of Europe (Janetzky 1994; Pöckl et al. 2003), it can be considered a suitable organism for assessing possible impacts of global change on species inhabiting springs. Furthermore, $G$. fossarum plays a fundamental role in organic matter breakdown in springs and spring brooks and hence in the distribution of coarse particulate organic matter (CPOM) and fine particulate organic matter (FPOM) (Wagner 1990; Simcic and Brancelj 2006). It was chosen as the test organism because of its abundant occurrence, its importance as an efficient shredder (Schmidt 2003) and its function as a key species in the ecosystem, breaking down leaf litter and so linking the terrestrial and aquatic ecosystems (Hieber and Gessner 2002). A set of experiments, in which the feeding and respiratory ETS activities of $G$. fossarum at different water temperatures were examined, were conducted.

The feeding activity of organisms has been observed in numerous experiments with gammarids, often on Gammarus pulex (Linnaeus 1758) (e.g. Pascoe et al. 1995; Graca et al. 2001; Felten et al. 2008) but also on G. fossarum (e.g. Dedourge-Geffard et al. 2009; Bundschuh et al. 2011) and is suitable to assess, for example, the effect of low concentrations of pollutants which are found in nature (Pestana et al. 2007). It is influenced by the choice of food, i.e. tree species they feed on. Most feeding tests described in the literature are conducted with Alnus glutinosa leaves (e.g. Maltby et al. 2002; Cold and Forbes 2004; Bundschuh et al. 2009), these being the preferred tree species of $G$. fossarum and other detritivores (Bloor 2009). The feeding activity is furthermore a simple way of assessing one aspect of the metabolic activity of the test organisms on the level of the organism.

The respiratory electron transport system (ETS) is an enzyme system found in the inner mitochondrial membranes of eucaryotes and controls the oxygen consumption (G.-Toth 1999). The results obtained from this assay reflect the maximum oxygen consumption when all enzymes are functioning optimally (Kenner and Ahmed 1975). The ETS assay was developed by Packard (1971) and improved by G.Toth (1999). Originally, the biochemical method for measuring respiration via the ETS was used to determine oxygen respiration of marine plankton (Packard 1971). Impairment of the organisms by elevated water temperature may have effects on the functioning of these enzymes and subsequently alter the ETS activity. The ETS assay is a useful tool to assess changes in the cellular level.

The aim of this study was to find out experimentally how $G$. fossarum reacts to varying and increasing water temperatures, which could occur in summer in Swiss springs. The hypotheses of this study were (1) that the feeding activity would increase at higher temperatures and (2) that the ETS activity would increase with increasing temperature and then decrease if the temperature reached the thermal tolerance limit of G. fossarum.

\section{Materials and methods}

\section{Chemicals}

Copper sulphate penta-hydrate $\left(\mathrm{CuSO}_{4} \cdot 5 \mathrm{H}_{2} \mathrm{O}\right.$, Merck, Lot no. A921690 717), magnesium sulphate heptahydrate $\left(\mathrm{MgSO}_{4} \cdot 7 \mathrm{H}_{2} \mathrm{O}\right.$, Merck, Lot no. A966886 729), formaldehyde solution min. $37 \%$ GR (HCHO, Merck, Lot no. K23876703 714), ortho-phosphoric acid $85 \%$ $\left(\mathrm{H}_{3} \mathrm{PO}_{4}\right.$, Merck, Lot no. K43024773 150) and potassium dihydrogen phosphate $\left(\mathrm{H}_{2} \mathrm{KPO}_{4}\right.$, Merck, Lot no. $\mathrm{K} 23916773$ 715) were purchased from Merck (Germany). Polyvinyl pyrrolidone (PVP) $\left[\left(\mathrm{C}_{6} \mathrm{H}_{9} \mathrm{NO}\right)_{\mathrm{x}}\right.$, Sigma Aldrich, Lot no. BCBG5331V], Triton-X-100 (Triton, Sigma Aldrich, Lot no. BCBC9283V), $\beta$ nicotinamide adenine dinucleotide, reduced disodium salt hydrate (NADH, Sigma Aldrich, Lot no. 071M7021V), $\beta$-nicotinamide adenine dinucleotide phosphate sodium salt hydrate (NADPH, Sigma Aldrich, Lot no. SLBH3107V), 2-p-iodo-phenyl-3-pnitrophenyl-5-phenyl tetrazolium chloride (INT, Sigma Aldrich, Lot no. BCBG6164V) and sodium phosphate dibasic dodeca-hydrate $\left(\mathrm{HNa}_{2} \mathrm{O}_{4} \mathrm{P} \cdot 12 \mathrm{H}_{2} \mathrm{O}\right.$, Sigma Aldrich, Lot no. SZBB201AV), were obtained from Sigma Aldrich (Germany). 
Choice of test organisms

Gammarus fossarum specimens were collected from one natural spring, a rheocrene, in the Röserental near Liestal, in Switzerland [for further information see von Fumetti and Nagel (2012)], and transported in spring water with leaves and stones to the laboratory. Individuals of both sexes were collected. Their size ranged from about 8 to $15 \mathrm{~mm}$ body length, the majority of the gammarids being about $10 \mathrm{~mm}$ long. The wet weight of the gammarids used in these experiments ranged from 8 to $14 \mathrm{mg}$. The selected test specimens showed no visible form of parasitism and moved actively before being used for the experiments. The gammarids were kept at $10{ }^{\circ} \mathrm{C}$ for three and a half days for acclimatisation to laboratory conditions before being used in an experiment.

\section{Conditioning of leaves}

Beech leaves (Fagus sylvatica L.) were collected from the litter layer near the spring from which the gammarids were obtained, after abscission in autumn 2011. As the spring is surrounded by beech trees, its leaves form the most important food source for many spring inhabitants including G. fossarum. The collected leaves were dried in an oven at $40{ }^{\circ} \mathrm{C}$. They were stored as described by Bloor (2010). Leaf discs $(\varnothing 1 \mathrm{~cm})$ were cut out of the collected leaves with the help of a cork borer. Twenty-eight leaf discs (more info see below) were always weighed together and then placed together in numbered stainless steel herb infusers $(\varnothing 9 \mathrm{~cm})$. This was important for the quantification of the feeding activity, described later on. There are many different ways of conditioning leaves (e.g. Malbouisson et al. 1995; Coulaud et al. 2011), and we decided not to use synthetic water mixtures. The herb infusers containing the leaf discs were submerged in aerated spring water with FPOM from the spring for conditioning for 4 weeks at $17^{\circ} \mathrm{C}$. The temperature was given by the room temperature and was chosen in order for conditioning to be more efficient.

\section{Test design}

The experiments were conducted in a laboratory in four stainless steel flow channels, with two control and two experimental channels. Each system consisted of the actual flow channel $(1 \mathrm{~m} \times 0.4 \mathrm{~m} \times 0.2 \mathrm{~m})$, a tube through which water flowed into a rain barrel $(60 \mathrm{~L})$ functioning as a water reservoir, an aquarium pump (EHEIM, compact 1000, Deizisau, Germany) to pump the water into the channel and a cooling unit (Aqua Medic Titan 500, Blessendorf, Germany) which helped regulate the water temperature, with an accuracy of $\pm 0.5^{\circ} \mathrm{C}$. Six plastic boxes $(78 \mathrm{~mm} \times$ $108 \mathrm{~mm} \times 67 \mathrm{~mm}$ ) from which two sides were removed and replaced by mesh (mesh width $1 \mathrm{~mm}$ ) in order for water to flow through them but to keep in the test organisms were placed in every channel. Seven test organisms were placed into each box. Each flow channel held three boxes for feeding tests and three boxes for the ETS analysis. Each box also held 28 leaf discs so that every gammarid had one leaf disc per week to feed on and sufficient foliage for shelter. Natural spring water was used from the spring from which the organisms were collected so that the presence of a natural microflora was given (Jonsson and Malmquist 2000). The photoperiod was adapted to the season, and the time changed once a fortnight to the current sunrise and sunset times. All flow channels were illuminated by two different aquaria lights (Juwel Aquarium warm-lite and Juwel Aquarium day-lite). The set-up of the experiments in the laboratory was deliberately as near-natural as possible.

The experiments lasted 26 days, during which time the water temperature was varied. The control groups were always kept at $10{ }^{\circ} \mathrm{C}$, and the experimental groups were varied for example as follows: first week $10{ }^{\circ} \mathrm{C}$, second and third week $14{ }^{\circ} \mathrm{C}$ and last week $14{ }^{\circ} \mathrm{C}$. In some regimes, the water temperature was decreased back to $10{ }^{\circ} \mathrm{C}$ in the fourth week to see whether the organisms would recover from the temperature elevation (Table 1). Many laboratory studies with gammarids use water temperatures of 12 to $16{ }^{\circ} \mathrm{C}$ (e.g. Cold and Forbes 2004; Bundschuh et al. 2009; Schaller et al. 2010; Coulaud et al. 2011). This seems rather high for $G$. fossarum collected from springs, which are usually found in springs and spring brooks in Switzerland with temperatures around $10{ }^{\circ} \mathrm{C}$ all year round, with absolute peaks of at most up to $14{ }^{\circ} \mathrm{C}$ (von Fumetti and Nagel 2012). Although it is unlikely that the water of the Swiss spring used in this study will ever reach temperatures of $18^{\circ} \mathrm{C}$, this temperature was chosen in order to ascertain the tolerance of the tested individuals of this species. The temperature changes were achieved within $24 \mathrm{~h}$. 
Table 1 Temperature regimes applied in the conducted experiments

\begin{tabular}{llcc}
\hline $\begin{array}{l}\text { Date of experiment } \\
\text { beginning (2012) Exp. 1-6 }\end{array}$ & $\begin{array}{l}\text { Temperature regime }=\text { conditions } \\
\left({ }^{\circ} \mathrm{C}\right) \text { weeks 1-2-3-4 }\end{array}$ & $\begin{array}{l}\text { Deaths control } \\
\text { groups }(\%)\end{array}$ & $\begin{array}{l}\text { Deaths experimental } \\
\text { groups }(\%)\end{array}$ \\
\hline 5th March & $10-14-14-10$ & 39.3 & 17.9 \\
2nd April & $10-14-14-14$ & 7.1 & 8.3 \\
30th April & $10-18-18-10$ & 7.1 & 33.3 \\
28th May & $10-18-18-18$ & 45.1 & 83.7 \\
25th June & $10-14-14-14$ & 65.3 & 55.1 \\
23rd July & $10-14-14-10$ & 42.9 & 45.2 \\
\hline
\end{tabular}

Control groups were always kept at $10^{\circ} \mathrm{C}$ for the entire experiment. The date indicates the start of the experiment. Deaths during the experiments are given in percentage

For the duration of the experiments oxygen saturation $(\%)$ and concentration $(\mathrm{mg} / \mathrm{L}), \mathrm{pH}$ and electrical conductivity $(\mu \mathrm{S} / \mathrm{cm})$ of the spring water in the flow channels were measured twice a week, using portable meters (Wissenschaftlich-Technische Werkstätten, Weilheim, Germany). The phosphate $\left(\mathrm{PO}_{4}{ }^{3-}\right)$, nitrate $\left(\mathrm{NO}_{3}{ }^{-}\right)$, nitrite $\left(\mathrm{NO}_{2}{ }^{-}\right)$and ammonia $\left(\mathrm{NH}_{4}{ }^{+}\right)$concentrations (all in $\mathrm{mg} / \mathrm{L}$ ) of the spring water in the flow channels were measured photometrically twice a week (Spectroquant NOVA 60, Merck, Darmstadt, Germany) to ensure that the water quality was stable.

Feeding activity

The organisms were monitored regularly for deaths, and dead gammarids were removed and preserved in $100 \%$ ethanol. At the end of the experiments, all gammarids were preserved in $100 \%$ ethanol and subsequently dried at $40{ }^{\circ} \mathrm{C}$ and then weighed. The leaf discs they had fed on were also dried at $40{ }^{\circ} \mathrm{C}$ and weighed. Additional replicates were set up to control leaf mass loss driven by abiotic factors and microbial decomposition. The results of these were used for the quantification of the feeding activity (=control factor). G. fossarum is a shredder, and hence not all processed, i.e. shredded leaf material is actually eaten; therefore, we refrain from using the term feeding rate and instead use the general term feeding activity. A feeding activity was determined for every box, for the seven organisms together, as described by Maltby et al. (2002) after the 26-day experiment duration:

$\mathrm{FA}=((\mathrm{Li} \times$ Control factor $)-\mathrm{Lf}) /($ weight $\times$ time $)$

where FA is the feeding activity, Li is the initial leaf weight $(\mathrm{mg})$, control factor is the loss of weight of leaves during 4 weeks when no feeding takes place, Lf is the final leaf weight (mg), weight is the dry weight of the gammarids $(\mathrm{mg})$ and time is the duration of the experiment (days).

\section{ETS activity}

The ETS analysis was conducted as described by Simcic and Brancelj (1997). ETS assays were carried out at the end of weeks one, three and four in order to detect the influence of the changing water temperatures on the organisms at the cellular level. For each experiment, 72 individuals were analysed, 24 individuals per week, i.e. 12 individuals from the control and 12 from the experimental group. Six live gammarids were removed from the flow channels one by one using tweezers, placed on a tissue and gently patted dry. They were then weighed singly on a microbalance (XP6, METTLER TOLEDO, Greifensee, Switzerland), placed on a numbered aluminium sheet with some distilled water. The gammarids were then homogenised singly in the homogenisation tube without the distilled water, using $4 \mathrm{~mL}$ of ice-cold homogenising buffer solution [0.1 M sodium phosphate buffer $\mathrm{pH} 8.4,75 \mu \mathrm{M} \mathrm{MgSO}, 0.15 \%$ (w/v) polyvinyl pyrrolidone, $0.2 \%$ (v/v) Triton-X-100]. The homogenate was poured into a centrifuge tube and sonicated with an ultrasonic homogeniser (Bandelin Sonopuls HD2070, Berlin, Germany) for $20 \mathrm{~s}$ and stored in an ice solution. The homogenate was then centrifuged (Sigma 2-16 PK, Osterode am Harz, Germany) at $0{ }^{\circ} \mathrm{C}$ for $4 \mathrm{~min}$ at $10,000 \mathrm{rpm}$, according to Simcic and Brancelj (2004). The supernatant (in triplicate) was incubated with $1.5 \mathrm{~mL}$ substrate solution [0.1 M sodium phosphate buffer $\mathrm{pH} 8.4,1.7 \mathrm{mM}$ NADH, $0.25 \mathrm{mM}$ NADPH, $0.2 \%$ (v/v) Triton-X-100] and $0.5 \mathrm{~mL}$ reagent solution [2.5 mM 2-p-iodo- 
phenyl-3-p-nitrophenyl-5-phenyl tetrazolium chloride] for $40 \mathrm{~min}$ at $10{ }^{\circ} \mathrm{C}$. Stopping solution [formaldehyde (conc.) $\mathrm{H}_{3} \mathrm{PO}_{4}$ (conc.) = 1:1], $0.5 \mathrm{~mL}$, was added immediately after incubation and the formazan production determined spectrophotometrically with the spectroquant ${ }^{\circledR}$ Pharo 300 (Merck, Darmstadt, Germany) by measuring the absorbance of the sample at $490 \mathrm{~nm}$ against the blank.The ETS activity was calculated according to Kenner and Ahmed (1975):

ETS activity $\left(\mu \mathrm{L} \mathrm{O}_{2} / \mathrm{mg} \times \mathrm{h}\right)$

$$
=\left(\mathrm{Abs}^{490 \mathrm{~nm}} \times \mathrm{Vr} \times \mathrm{Vh} \times 60\right) /(\mathrm{Va} \times \mathrm{Gw} \times t \times 1.42)
$$

where $\mathrm{Abs}^{490 \mathrm{~nm}}$ is the absorption of the sample, $\mathrm{Vr}$ is the final volume of the reaction mixture $(3 \mathrm{~mL}), \mathrm{Vh}$ is the volume of the original homogenate $(4 \mathrm{~mL}), \mathrm{Va}$ is the volume of the aliquot of the homogenate $(0.5 \mathrm{~mL})$, $\mathrm{Gw}$ is the gammarid wet weight $(\mathrm{mg}), t$ is the incubation time (minutes) and 1.42 is the factor for conversion to volume oxygen.

Data analysis

The analyses of variances (ANOVAs) were calculated using the Statistical Package for Social Sciences (SPSS) version 21 for Windows (SPSS Inc, Chicago, IL, USA). One-way ANOVAs were conducted to test the influence of the water temperatures on the feeding and ETS activities of the test organisms.

Variance homogeneity was tested with the Levene test. The feeding activity data were found to be homogeneous. To correct for multiple single comparisons, a Bonferroni-Holm correction was applied. For the ETS data, variance was found to be unequal. A reason for this is because very small sample sizes may be particularly sensitive to the homogeneity of variance assumption. A Games-Howell test, which is applied in such cases of unequal variances and also takes unequal group sizes into account, was applied to the ETS data. The $\alpha$-level was set at 0.05 .

\section{Results}

Feeding activity

The results demonstrate higher feeding activities at higher temperatures, being highest in condition 10$18-18-18^{\circ} \mathrm{C}$. The lowest measured feeding activity was $0.03 \mathrm{mg} / \mathrm{mg} \times \mathrm{d}$ at $10{ }^{\circ} \mathrm{C}$; the highest one was $3.37 \mathrm{mg} / \mathrm{mg} \times \mathrm{d}$, measured at $18{ }^{\circ} \mathrm{C}$.

An ANOVA comparing the different temperature regimes revealed a significant effect on the feeding activity, $F_{4,67}=12.537, p<0.001$. Further single comparisons were calculated using the BonferroniHolm correction. The feeding activities in the control $(M=0.09, \mathrm{SD}=0.04)$ were significantly lower than in conditions $10-14-14-14{ }^{\circ} \mathrm{C}(M=0.14, \mathrm{SD}=0.04)$ and $10-18-18-18{ }^{\circ} \mathrm{C} \quad(M=0.20, \quad \mathrm{SD}=0.09) \quad(p<$ 0.005 and $p<0.001$, respectively) (Fig. 1a). No significant differences could be made out between the control and conditions $10-14-14-10{ }^{\circ} \mathrm{C}(M=0.09$, $\mathrm{SD}=0.03)$ and $10-18-18-10{ }^{\circ} \mathrm{C}(M=0.07, \mathrm{SD}=$ 0.01) ( $p=1.0$ and $p=1.0$, respectively) (Fig. 1b).

Although $83.7 \%$ of the organisms died in condition 10-18-18-18 ${ }^{\circ} \mathrm{C}$ (Table 1), the surviving gammarids shredded significantly more than those in the control. Significant differences also exist between condition $10-14-14-10{ }^{\circ} \mathrm{C} \quad(M=0.09, \quad \mathrm{SD}=0.03)$ and $\quad 10-14-14-14{ }^{\circ} \mathrm{C} \quad(M=0.14, \quad \mathrm{SD}=0.04)$ $(p=0.040)$. Lastly, the difference between condition $10-18-18-10{ }^{\circ} \mathrm{C} \quad(M=0.07, \quad \mathrm{SD}=0.01)$ and
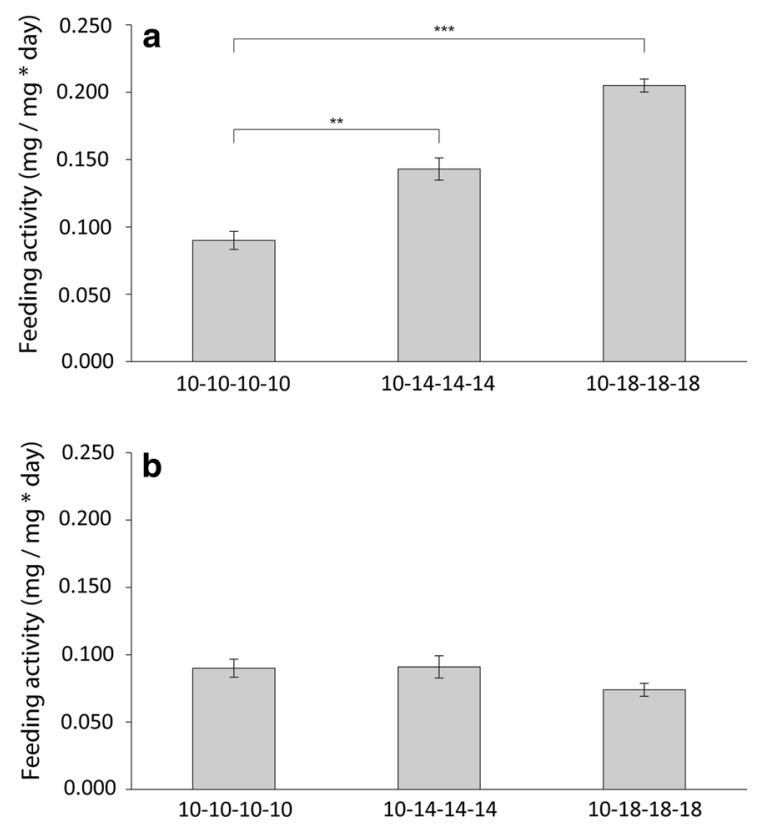

Fig. 1 a, b Mean feeding activities at the different conditions. The control is always at $10{ }^{\circ} \mathrm{C}$, and the experimental temperature regimes range between 10 and $18{ }^{\circ} \mathrm{C}$. Standard errors are represented in the figure by the error bars attached to each column. Note: $* * *<0.001, * *<0.005$ 
$10-18-18-18{ }^{\circ} \mathrm{C}(M=0.20, \mathrm{SD}=0.09)$ was found to be significant $(p<0.001)$.

ETS activity

Generally, mean ETS values are in a similar range. The lowest measured ETS activity was $0.105 \mu \mathrm{L} \mathrm{O} /$ $\mathrm{mg} \times \mathrm{h}$; the highest one was $1.142 \mu \mathrm{L} \mathrm{O} \mathrm{O}_{2} / \mathrm{mg} \times \mathrm{h}$, both measured at $10{ }^{\circ} \mathrm{C}$.

An ANOVA comparing the different temperature regimes revealed no significant effect on the ETS activity, $F_{7,360}=1.831, p=0.080$. When looking at the conditions which lasted 3 weeks and then at the conditions which lasted 4 weeks, it can be noted that a bell-shaped curve could be drawn over the three bars (Fig. 2a, b).

In condition $10-18-18-18{ }^{\circ} \mathrm{C}$, the organisms destined for ETS analysis had died before the end of week 4. The reason for the many deaths $(83.7 \%)$ in this condition was probably entirely owing to the high temperature of $18{ }^{\circ} \mathrm{C}$, with which the test organisms
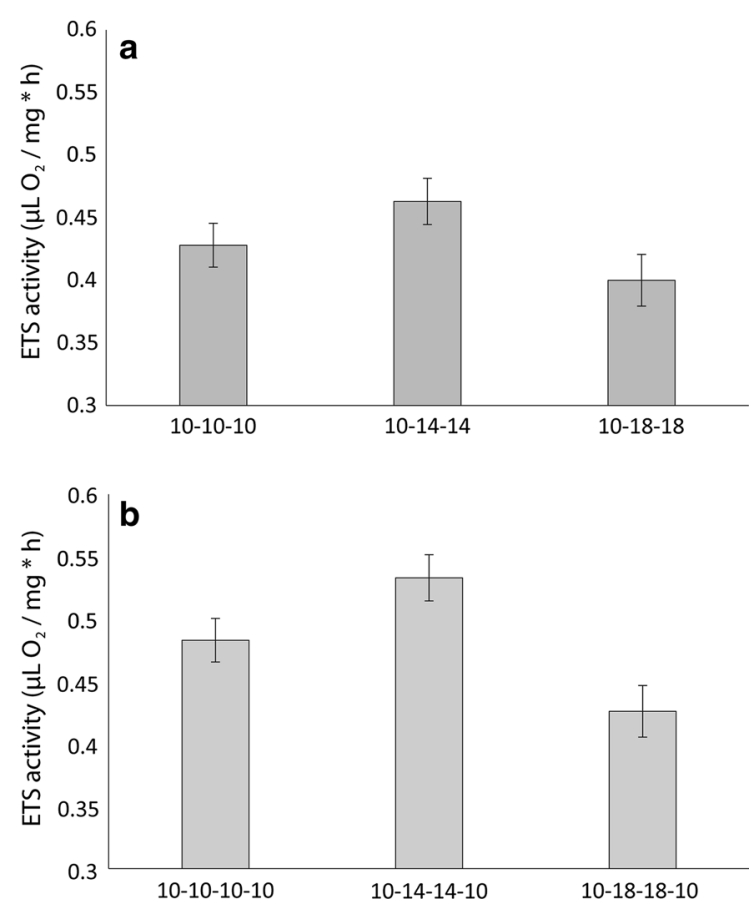

Fig. 2 Mean ETS activities of the conditions lasting 3 weeks (a) and those lasting 4 weeks, with the temperature regimes that declined after 3 weeks back to $10{ }^{\circ} \mathrm{C}(\mathbf{b})$. The control conditions are always at $10^{\circ} \mathrm{C}$, and the experimental temperature regimes range between $10{ }^{\circ} \mathrm{C}$ and $18{ }^{\circ} \mathrm{C}$. Standard errors are represented in the figure by the error bars attached to each column were not able to cope for longer than 3 weeks. In the other conditions, the average death rate was around $30 \%$ (Table 1).

\section{Discussion}

Feeding activity of $G$. fossarum

The conducted feeding tests demonstrate that higher temperatures increase the feeding activity of $G$. fossarum and therefore have an impact on G. fossarum on the organismal level. Higher temperatures generally cause higher metabolic rates (e.g. Georgiadis 1977). In addition, it has also been observed that the consumption of stream-water-conditioned alder leaves by $G$. pulex increased with increasing temperatures (Malbouisson et al. 1994). Feeding tests conducted with G. pulex at 2, 5, 10 and $15{ }^{\circ} \mathrm{C}$ with Alnus sp. and Fagus sp. leaves caused a rise in consumption with increasing temperature (Nilsson 1974). It would appear in this study that the conditions with the temperature regimes involving $14{ }^{\circ} \mathrm{C}$ were not stressful for the gammarids but might even be considered more optimal for these organisms. The feeding activity in the conditions $10-14-14-10{ }^{\circ} \mathrm{C}$ and $10-18-18-10{ }^{\circ} \mathrm{C}$ was not significantly higher than the feeding activity of the control. It can be argued that a decrease in temperature after 2 weeks of an elevated water temperature normalises the feeding activity so that the overall feeding activity ends up not significantly different from the feeding activity in the control condition. In this case, a decrease in water temperature after the initial elevation has a stabilizing effect on the organisms' metabolism. It was assumed that higher temperatures would raise mortality; indeed, this was the case at $18{ }^{\circ} \mathrm{C}$. This temperature was too warm for the gammarids, and the surviving ones were stressed by an elevation of their metabolic activity.

The sex of the test organisms can influence the feeding activity (Malbouisson et al. 1994). In all the experiments, females and males were used without determining their sexes, since determination would cause unnecessary stress of the test organisms. Also, we aimed at conducting the experiments as nearnaturally as possible. However, it was always ensured that specimens of similar size compositions were used in the experiments. For G. pulex, it has been shown that females consumed less food than males in terms of 
absolute dry weight (Malbouisson et al. 1994). It can be assumed that females of $G$. fossarum behave likewise, and therefore, certain observed feeding activities are potentially lower than others owing to the sex of the organisms used. However, it should be noted that natural differences in appetites of individuals can also have an effect on the feeding activity (Taylor et al. 1993). Certain results may also be affected by the fact that some test organisms moulted during the tests. In those cases, it was observed that they often died within the following 24 h. G. fossarum specimens were also used regardless of the time of their last moult in tests conducted by Simcic and Brancelj (2003).

\section{ETS activity of G. fossarum}

The measured ETS activities in this study are in a similar range to ETS activities measured by other authors (e.g. Simcic et al. 2005; Simcic and Brancelj 2006; Lukancic et al. 2010). It was assumed that ETS activity, i.e. the enzyme activity, would increase with increasing temperatures as demonstrated by Simcic and Germ (2010) up to a turning point and then decrease.

The ETS activities measured after 3 weeks, comparing the temperature regimes $10-10-10{ }^{\circ} \mathrm{C}, 10-14$ $14{ }^{\circ} \mathrm{C}$ and $10-18-18{ }^{\circ} \mathrm{C}$, were not significantly different. However, it would appear that the ETS activity increased in the condition $10-14-14{ }^{\circ} \mathrm{C}$ but decreased in the condition $10-18-18{ }^{\circ} \mathrm{C}$, compared to the mean ETS activity of the control channel kept at $10{ }^{\circ} \mathrm{C}$ during the 3 weeks. The same pattern is observed when comparing the ETS activities measured after 4 weeks, comparing the temperature regimes 10-10$10-10{ }^{\circ} \mathrm{C}, 10-14-14-10{ }^{\circ} \mathrm{C}$ and $10-18-18-10{ }^{\circ} \mathrm{C}$. In natural environments, $G$. fossarum competes with $G$. pulex. Gammarus pulex is more robust towards higher water temperatures up to $27{ }^{\circ} \mathrm{C}$ (Sutcliffe et al. 1981; Foucreau et al. 2014), and so G. fossarum is forced into colder waters. An intermediate temperature such as $14^{\circ} \mathrm{C}$ is probably more suitable for $G$. fossarum than $10{ }^{\circ} \mathrm{C}$. However, higher water temperatures than $14{ }^{\circ} \mathrm{C}$, for example $18{ }^{\circ} \mathrm{C}$, were shown to have detrimental effects on $G$. fossarum, which could lead this species and other more sensitive species into survival difficulties.

In order to understand the results obtained in this study, it needs to be pointed out that the ETS activities of the gammarids in this study were measured 1 week after changing the water temperature. This gave the gammarids a week to adapt to the new temperature: probably long enough for them to recover and stabilize their normal ETS activity. This adaption would explain the similar values of the control to the experimental conditions. In an experiment with daphnids at different temperatures, an adaptation time to experimental temperatures of only $3 \mathrm{~h}$ was given (Simcic and Brancelj 1997). It has been shown that a certain time span enables adaptation of the species to the new circumstances (e.g. Bamsted 1980). Organisms which live in relatively stable temperature environments, such as spring species, are not well adapted to temperature fluctuations. In such cases, ETS activity is more sensitive to temperature variations (Simcic and Brancelj 1997). Therefore, it can be assumed that $G$. fossarum will react in a similar way when little time to adapt is given. It can also be assumed that the observed pattern, an increase at the intermediate temperature regime with $14{ }^{\circ} \mathrm{C}$ but a decrease at the extreme temperature regime with $18{ }^{\circ} \mathrm{C}$, would become significant if adaptation time was considerably shortened. This will be a subject for future investigation. The findings also give an insight into the high adaptability of $G$. fossarum towards intermediate temperature elevations. The results do not suggest that a gradual temperature increase on its own, caused by global change, will be as problematic for $G$. fossarum on the cellular level as initially thought.

Implications on the population and community level

Water temperature has a dominating influence on the life history, reproduction and growth of G. fossarum (Pöckl et al. 2003). In this study, it was shown that higher water temperatures caused higher feeding activities. This has consequences for G. fossarum on the population level, as a higher feeding activity induced by higher water temperatures as a direct consequence of global change could result in a faster depleted food source. Springs are dependent on allochtonous material input. For example, the spring the gammarids were taken from for this study is situated in a forest with a limited number of trees surrounding it. By the end of summer, hardly any leaf litter is left in the springs. If the water temperature 
rises as predicted, and the feeding activity rises as observed in this study, then food might become scarce by the end of summer and so become a limiting factor for the organisms living in these ecotones. This food shortage in return could result in the reduction or complete stop of the individual's scope for growth. This in turn might decrease the amount of energy available for reproduction and decreases the individual's probability of survival (Naylor et al. 1990; Maltby 1992).

On the community level, G. fossarum acts as a shredder, breaking down CPOM to FPOM (Wagner 1990; Simcic and Brancelj 2006). Therefore, it plays a very important role in the lotic food web of springs, enabling other species to survive on the FPOM provided. Increased water temperatures could therefore cause larger FPOM production. This may be positive for species dependent on that food source, given that they survive the elevated water temperatures.

According to the results, $14{ }^{\circ} \mathrm{C}$ seems to pose no serious problems for $G$. fossarum, but other species living in springs might be affected more strongly by such an increase in water temperature, because they are adapted to a relatively stable environment. In consequence, elevated water temperature could change whole species assemblages and alter the susceptibility of macroinvertebrates to environmental stressors such as pesticides, pharmaceuticals or illnesses. A water temperature of $14{ }^{\circ} \mathrm{C}$ has indeed been measured in the spring used in this study in summer during especially warm periods.

Generally, elevated water temperatures may cause physiological stress, rising metabolic activity and in consequence reduced fitness (Hering et al. 2010). The body temperature of most invertebrates fluctuates with the temperature of their immediate environment; subsequently, the ETS activity of these species must function under a wide range of temperatures (Simcic et al. 2014). This requirement is however not met by cold water adapted species. Supporting this, it has been demonstrated that cold-stenothermal chironomids had a lower ETS activity at high water temperatures (Simcic 2005).

In response to global change, species are already expanding their ranges to higher latitudes and altitudes (Krajick 2004; Heino et al. 2009). In particular, coldstenothermal species will experience strong range shifts or range contractions, as space with suitable thermal conditions decreases (Woodward et al. 2010).

Extreme weather events in Europe are becoming more frequent owing to global change, and so temperature fluctuations such as those used in these experiments will become increasingly important.

\section{Conclusion}

By studying the feeding and the ETS activity of $G$. fossarum exposed to elevated water temperatures, the aim was to benefit from the simplicity of the one method on the level of the organism and complexity of the other method on the cellular level. Although the approach of these two methods is different, the results obtained by them should be complementary in assessing the responses of the test organisms. The feeding activity of $G$. fossarum at elevated water temperatures increased significantly. The measured ETS activities were not significantly different at increased temperatures. Reasons why the ETS activities of the gammarids did not increase significantly are discussed. With the results of these experiments, it can be concluded that $G$. fossarum is suitable to help evaluate changes occurring in spring ecotones. It was shown that G. fossarum is able to adapt to short-term intermediate temperature elevations quickly and is hence not necessarily threatened by moderately rising water temperatures. Moreover, global change is interacting with other stressors, for example pesticides (Durance and Ormerod 2007), and will result in complex cause-effect chains as many other environmental parameters are linked to temperature (Hering et al. 2010). Future research will concentrate on tests with $G$. fossarum under the influence of an additional stressor, with less time being allowed for adaption to the changed environmental circumstances.

Acknowledgments Financial support was provided by the Janggen-Pöhn-Stiftung. T. Simcic kindly introduced us to the ETS assay. C. Clarke proof-read the manuscript. I. Röthele conducted a few experiments testing for differences between the sexes of the gammarids and their ETS activity. Thanks are owing to four anonymous reviewers who made valuable comments on the manuscript. Thanks are also owing to further numerous people, especially to the first author's family for valuable technical support and discussion.

Conflict of interest The authors declare that they have no conflict of interest. 


\section{References}

Bamsted U (1980) ETS activity as an estimator of respiratory rate of zooplankton populations. The significance of variations in environmental factors. J Exp Mar Biol Ecol 42:267-283

Bloor M (2009) Aquatic pollution. Case study of landfill leachate toxicity and remediation. VDM Verlag Dr. Müller Aktiengesellschaft \& Co. KG, Saarbrücken

Bloor MC (2010) Animal standardisation for mixed species ecotoxicological studies: establishing a laboratory breeding programme for Gammarus pulex and Asellus aquaticus. Zool Baetica 21:179-190

Bundschuh M, Hahn T, Gessner MO, Schulz R (2009) Antibiotics as a chemical stressor affecting an aquatic decomposer-detritivore system. Environ Toxicol Chem 28:197-203

Bundschuh M, Zubrod JP, Kosol S, Maltby L, Stang C, Duester L, Schultz R (2011) Fungal composition on leaves explains pollutant-mediated indirect effects on amphipod feeding. Aquat Toxicol 104:32-37

Cantonati M, Gerecke R, Bertuzzi E (2006) Springs of the Alps-sensitive ecosystems to environmental change: from biodiversity assessments to long-term studies. Hydrobiologia 562:59-96

Carpenter SR, Fisher SG, Grimm NB, Kitchell JF (1992) Global Change and freshwater ecosystems. Annu Rev Ecol Syst 23:119-139

Cold A, Forbes VE (2004) Consequences of a short pulse of pesticide exposure for survival and reproduction of Gammarus pulex. Aquat Toxicol 67:287-299

Coulaud R, Geffard O, Xuereb B, Lacaze E, Quéau H, Garric J, Charles S, Chaumot A (2011) In situ feeding assay with Gammarus fosssarum (Crustacea): modelling the influence of confounding factors to improve water quality biomonitoring. Water Res 45:6417-6429

Dedourge-Geffard O, Palais F, Biagianti-Risbourg S, Geffard O, Geffard A (2009) Effects of metals on feeding rate and digestive enzymes in Gammarus fossarum: an in situ experiment. Chemosphere 77:1569-1576

Della-Marta PM, Haylock MR, Luterbacher J, Wanner H (2007) Doubled length of western European summer heat waves since 1880. J Geophys Res Atmos 112:D15103

Durance I, Ormerod SJ (2007) Climate change effects on upland stream macroinvertebrates over a 25 -year period. Glob Change Biol 13:942-957

Felten V, Charmantier G, Mons R, Geffard A, Rousselle P, Coquery M, Garric J, Geffard O (2008) Physiological and behavioural responses of Gammarus pulex (Crustacea: Amphipoda) exposed to cadmium. Aquat Toxicol 86:413-425

Fischer J, Fischer F, Schnabel S, Bohle HW (1998) Spring fauna of the Hessian Mittelgebirge: population structure, adaptative strategies, and relations to habitats of the macroinvertebrates, as exemplified by springs in the Rhenisch metamorphic shieldand in the East-Hessian sandstone plate. In: Botosaneanu L (ed) Studies in crenobiology. The biology of springs and springbrooks. Backhuys Publishers, Leiden, pp 182-199
Foucreau N, Cottin D, Piscart C, Hervant F (2014) Physiological and metabolic responses to rising temperature in Gammarus pulex (Crustacea) populations living under continental or Mediterranean climates. Comp Biochem Physiol Part A 168:69-75

Georgiadis G (1977) Die Auswirkung verschiedener Temperaturund Salinitätskombinationen auf Gammarus fossarum Koch, 1835. Crustaceana Supplement, Number 4, Studies in Gammaridae. In: Proceedings of the 3rd International Colloquium on Gammarus and Niphargus, Schlitz, 1975, 112-119

Graca MAS, Cressa C, Gessner MO, Feio MJ, Callies KA, Barrios C (2001) Food quality, feeding preferences, survival and growth of shredders from temperate and tropical streams. Freshw Biol 46:947-957

G.-Toth L (1999) Aktivität des Elektronentransportsystems. In: von Tümpling W, Friedrich G (eds) Biologische Gewässeruntersuchung. Methoden der Biologischen Wasseruntersuchung 2. Gustav Fischer Verl, Jena, Stuttgart, Lübeck, Ulm, pp 465-473

Hegerl G, Hanlon H, Beierkuhnlein C (2011) Elusive extremes. Nat Geosci 4:142-143

Heino J, Virkkala R, Toivonen H (2009) Climate change and freshwater biodiversity: detected patterns, future trends and adaptations in northern regions. Biol Rev 84:39-54

Hering D, Haidekker A, Schmidt-Kloiber A, Barker T, Buisson L, Graf W, Grenouillet G, Lorenz A, Sandin L, Stendera S (2010) Monitoring the responses of freshwater ecosystems to climate change. In: Kernan M, Battarbee RW, Moss B (eds) Climate change impacts on freshwater ecosystems. Wiley, Chichester, pp 84-118

Hieber M, Gessner MO (2002) Contribution of stream detritivores, fungi, and bacteria to leaf breakdown based on biomass estimates. Ecology 83:1026-1038

IPCC 2007. Climate Change, 2007. Synthesis Report. In: Pachauri RK, Reisinger A (eds) Contribution of working Groups 1, 2 and 3 to the Fourth Assessment Report of the Intergovernmental Panel on Climate Change. IPCC, Geneva, Switzerland

Janetzky W (1994) Distribution of the genus Gammarus (Amphipoda: Gammaridae) in the River Hunte and its tributaries (Lower Saxony, northern Germany). Hydrobiologia 294:23-34

Jonsson M, Malmquist B (2000) Ecosystem process rate increases with animal species richness: evidence from leafeating, aquatic insects. Oikos 89:519-523

Kenner RA, Ahmed SI (1975) Measurements of electron transport activities in marine phytoplancton. Mar Biol 33:119-127

Krajick A (2004) All downhill from here? Science 303:1601-1602

Lukancic S, Zibrat U, Mezek T, Jerebic A, Simcic T, Brancelj A (2010) A new method for early assessment of effects of exposing two non-target crustacean species, Asellus aquaticus and Gammarus fossarum, to pesticides, a laboratory study. Toxicol Ind Health 26:217-228

Malbouisson JFC, Young TWK, Bark AW (1994) Disruption of Precopula in Gammarus Pulex as a result of brief exposure to gamma-hexachlorocyclohexane (lindane). Chemosphere 28:2011-2020 
Malbouisson JFC, Young TWK, Bark AW (1995) Use of feeding rate and repairing of precopulatory Gammarus pulex to assess toxicity of gamma-hexachlorocyclohexane (lindane). Chemosphere 30:1573-1583

Maltby L (1992) The use of the physiological energetics of Gammarus pulex to assess toxicity: a study using artificial streams. Environ Toxicol Chem 11:79-85

Maltby L, Clayton SA, Wood RM, McLoughlin N (2002) Evaluation of the Gammarus pulex in situ feeding assay as a biomonitor of water quality: robustness, responsiveness, and relevance. Environ Toxicol Chem 21:361-368

Naylor C, Maltby L, Calow P (1990) Scope for growth in Gammarus pulex, a freshwater benthic detritivore. Hydrobiologia 188(189):517-523

Nilsson LM (1974) Energy budget of a laboratory population of Gammarus pulex (Amphipoda). Oikos 25:35-42

Packard TT (1971) The measurement of respiratory electron transport system activity in marine phytoplankton. J Mar Res 29:235-244

Pascoe D, Kedwards TJ, Blockwell SJ, Taylor EJ (1995) Gammarus pulex (L.) feeding bioassay-effects of parasitism. Bull Environ Contam Toxicol 55:629-632

Pestana JLT, Re A, Nogueira AJA, Soares AMVM (2007) Effects of Cadmium and Zinc on the feeding behaviour of two freshwater crustaceans: Atyaephyra desmarestii (Decapoda) and Echinogammarus meridionalis (Amphipoda). Chemosphere 68:1556-1562

Pöckl M, Webb BW, Sutcliffe DW (2003) Life history and reproductive capacity of Gammarus fossarum and $G$. roeseli (Crustacea: Amphipoda) under naturally fluctuating water temperatures: a simulation study. Freshw Biol 48:53-66

Schaller J, Mkandawire M, Dudel EG (2010) Heavy metals and arsenic fixation into freshwater organic matter under Gammarus pulex L. influence. Environ Pollut 158: 2454-2458

Schmidt J (2003) Wirkung von Umweltchemikalien auf Gammarus fossarum. Populationsexperimente und individuenbasiertes Reproduktionsmodell. Dissertation, Technische Universität Dresden, Dresden 1-10

Simcic T (2005) Respiratory electron transport system (ETS) activity and respiration rate in cold-stenothermal and eurythermal chironomid larvae from high-mountain lakes. Arch für Hydrobiol 162:399-415

Simcic T, Brancelj A (1997) Electron transport system (ETS) activity and respiration rate in five Daphnia species at different temperatures. Hydrobiologia 360:117-125
Simcic T, Brancelj A (2003) Estimation of the proportion of metabolically active mass in the amphipod Gammarus fossarum. Freshw Biol 48:1093-1099

Simcic T, Brancelj A (2004) Respiratory electron transport system (ETS) activity as an estimator of the thermal tolerance of two Daphnia hybrids. J Plankton Res 26:525-534

Simcic T, Brancelj A (2006) Effects of pH on electron transport system (ETS) activity and oxygen consumption in Gammarus fossarum, Asellus aquaticus and Niphargus sphagnicolus. Freshw Biol 51:686-694

Simcic T, Germ M (2010) Increased temperature due to global warming alters the respiratory potential in aquatic organisms from an oligotrophic lake. Research paper. Internat Rev Hydrobiol 95:370-382

Simcic T, Lukancic S, Brancelj A (2005) Comparative study of electron transport system activity and oxygen consumption of amphipods from caves and surface habitats. Freshw Biol 50:494-501

Simcic T, Pajk F, Jaklic M, Brancelj A, Vrezec A (2014) The thermal tolerance of crayfish could be estimated from respiratory electron transport system activity. J Therm Biol 41:21-30

Sutcliffe DW, Carrick TR, Willoughby LG (1981) Effects of diet, body size, age and temperature on growth rates in the amphipod Gammarus pulex. Freshw Biol 11:183-214

Taylor EJ, Jones DPW, Maund SJ, Pascoe D (1993) A new method for measuring the feeding activity of Gammarus Pulex (L.). Chemosphere 26:1375-1381

van der Kamp RO (1995) The hydrogeology of springs in relation to the biodiversity of spring fauna: a review. J Kans Entomol Soc 68:4-17

Vittoz P, Cherix D, Gonseth Y, Lubini V, Maggini R, Zbinden N, Zumbach S (2013) Climate change impacts on biodiversity in Switzerland: a review. J Nat Conser 21:154-162

Von Fumetti S, Nagel P (2012) Discharge variability and its effect on faunistic assemblages in springs. Freshw Sci 31:647-656

Von Fumetti S, Nagel P, Baltes B (2007) Where a springhead becomes a springbrook - a regional zonation of springs. Fundam Appl Limnol 169:37-48

Wagner R (1990) Influence of temperature, photoperiod and nutrition on growth and consumption of Chaetopteryx Villosa (Trichoptera). Holarct Ecol 13:247-254

Woodward G, Perkins DM, Brown LE (2010) Climate change and freshwater ecosystems; impacts across multiple levels of organization. Philos Trans R Soc B 365:2093-2106 